\title{
Genotype-phenotype analysis of recombinant chromosome 4 syndrome: an array-CGH study and literature review
}

\author{
Morteza Hemmat ${ }^{1,3^{*}}$, Omid Hemmat ${ }^{2 \dagger}$, Arturo Anguiano ${ }^{1}$, Fatih Z Boyar ${ }^{1}$, Mohammed El Naggar ${ }^{1}$, Jia-Chi Wang ${ }^{1}$,
} Borris T Wang ${ }^{1}$, Trilochan Sahoo ${ }^{1}$, Renius Owen ${ }^{1}$ and Mary Haddadin ${ }^{1}$

\begin{abstract}
Background: Recombinant chromosome 4, a rare constitutional rearrangement arising from pericentric inversion, comprises a duplicated segment of $4 p 13 \sim p 15 \rightarrow 4 p t e r$ and a deleted segment of $4 q 35 \rightarrow 4 q$ ter. To date, 10 cases of recombinant chromosome 4 have been reported.

Result: We describe the second case in which array-CGH was used to characterize recombinant chromosome 4 syndrome. The patient was a one-year old boy with consistent clinical features. Conventional cytogenetics and FISH documented a recombinant chromosome 4, derived from a paternal pericentric inversion, leading to partial trisomy $4 p$ and partial monosomy of $4 q$. Array-CGH, performed to further characterize the rearranged chromosome 4 and delineate the breakpoints, documented a small (4.36 Mb) 4q35.1 terminal deletion and a large (23.81 Mb) 4p15.1 terminal duplication. Genotype-phenotype analysis of 10 previously reported cases and the present case indicated relatively consistent clinical features and breakpoints. This consistency was more evident in our case and another characterized by array-CGH, where both showed the common breakpoints of p15.1 and q35.1. A genotypephenotype correlation study between rec(4), dup(4p), and del(4q) syndromes revealed that urogenital and cardiac defects are probably due to the deletion of $4 q$ whereas the other clinical features are likely due to $4 p$ duplication.

Conclusion: Our findings support that the clinical features of patients with rec(4) are relatively consistent and specific to the regions of duplication or deletion. Recombinant chromosome 4 syndrome thus appears to be a discrete entity that can be suspected on the basis of clinical features or specific deleted and duplicated chromosomal regions.
\end{abstract}

Keyword: Recombinant chromosome 4, Pericentric inversion, Array-CGH, Genotype-phenotype analysis

\section{Background}

Pericentric inversions are observed with varying frequency in all human chromosomes. Breakpoint regions of chromosomal inversions often contain high densities of repetitive DNA sequences, such as Alu and L1 elements, leading to speculation that they could mediate chromosomal rearrangements and serve as hot spots for non-allelic homologous recombination (NAHR) [1].

\footnotetext{
* Correspondence: morteza.x.hemmat@questdiagnostics.com

${ }^{\dagger}$ Equal contributors

'Cytogenetics Department, Quest Diagnostics Nichols Institute, San Juan Capistrano, CA, USA

${ }^{3}$ Cytogenetics Department, Quest Diagnostics Nichols Institute, 33608 Ortega Highway, San Juan Capistrano, CA 92690, USA

Full list of author information is available at the end of the article
}

During meiosis in carriers, a chromosome containing a large inverted segment and its normal homolog are predicted to form a homosynaptic inversion loop, which leads to optimal pairing of the matching segment [2]. The number of chiasmata in the inverted segment is thought to directly correlate the size of the inverted segment [3-5]. Any odd number of crossovers within the inversion loop leads to the production of two alternate recombinant chromosomes: in one chromosome the distal part of the short arm is duplicated and the distal part of the long arm is deleted; the opposite occurs in the other chromosome. Consequently, two alternative recombinants are theoretically possible among the offspring and generally only one is compatible with life,

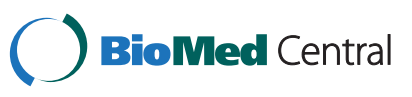


since, large deletions seem to have a more deleterious effect than large duplications $[1,3,6,7]$.

The chromosome 4 inversion involving sub-band p14 p15 and q35 results in two types of recombinant chromosome 4 . Approximately $80 \%$ of the viable recombinants are partial $4 \mathrm{p}$ duplications and $4 \mathrm{q}$ deletions [8]. To date, 10 such cases of recombinant chromosome 4 have been reported [9-18]. We report on a one-year old boy carrying a recombinant chromosome 4 with partial duplication of $4 \mathrm{p}$ and partial deletion of $4 \mathrm{q}$, resulting from paternal pericentric inversion of chromosome 4 with breakpoints at 4p15.1 and 4q35.1. The breakpoints and the size of duplicated and deleted segments were studied using conventional chromosome analysis, FISH, and array-CGH. A genotypic-phenotypic correlation analysis was performed between the present case and previously reported cases of rec(4) syndromes, and also between the $\operatorname{rec}(4), \operatorname{dup}(4 \mathrm{p})$, and $\operatorname{del}(4 \mathrm{q})$ syndromes, to further define the relationship of specific chromosomal rearrangements with clinical features.

\section{Clinical description}

The patient is a one year-old male who presented clinically with developmental delay, dysmorphic features including microcephaly, broad nose with anteverted nares, thin upper lips, abnormal ears, short neck, broad chest, and cardiac and genital anomalies. Both parents were apparently normal; however the father was diagnosed with a pericentric inversion of chromosome 4 by prenatal chromosome analysis. Prenatal testing in the paternal grandmother was medically requested following the earlier death of her daughter due to congenital abnormalities. Grandmaternal chromosome analysis confirmed that the father's inverted chromosome 4 was inherited from his mother (the grandmother of the index case).

\section{Results}

Chromosome analysis of cultured lymphocytes by Gbanding revealed 46 chromosomes in all cells, with an abnormal chromosome 4 containing a deletion of 4q35.1-qter and a duplication of 4p15.1-pter. The normal and the recombinant chromosome 4 and their ideograms are shown in Figure 1.

Duplication of $4 \mathrm{p}$ and deletion of $4 \mathrm{q}$ in the recombinant chromosome were also confirmed by using probes specific for sub-telomeric $4 \mathrm{p}$ and $4 \mathrm{q}$ (Figure 2). Only the normal chromosome 4 showed signals from both $4 \mathrm{p}$ and 4q sub-telomeric probes. The recombinant chromosome 4 showed double and symmetrical signals of the $4 \mathrm{p}$ subtelomeric probe but no signal for $4 \mathrm{q}$, since the $4 \mathrm{q}$ subtle region was deleted and $4 \mathrm{p}$ was duplicated.

Array-CGH analysis confirmed the partial duplication of 4p15.1-pter and partial deletion of 4q35-qter. The duplicated segment spanned 23.81 Mb, from Bac prob

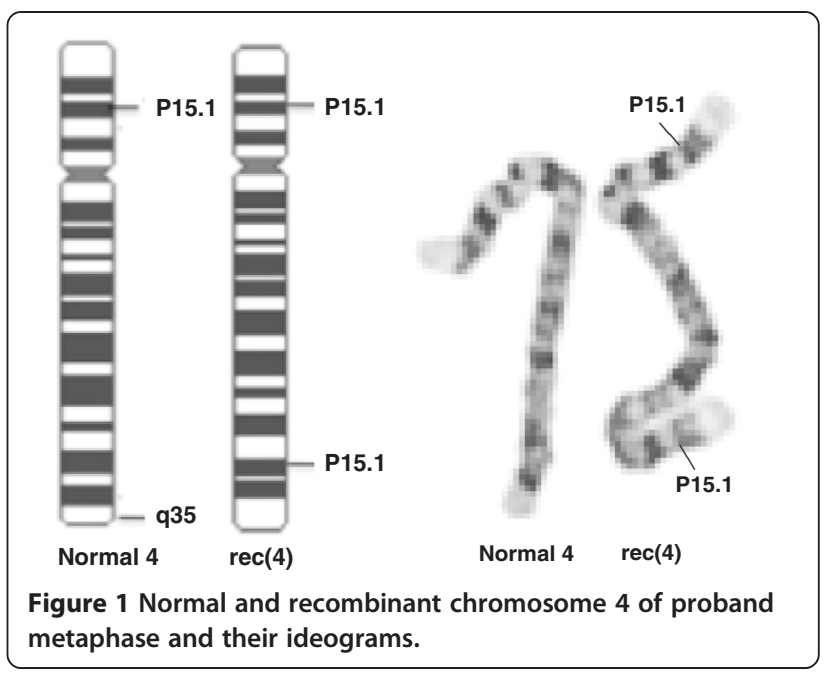

CTD-218L8 to RP11-405D14. The deleted segment spanned 4.36 Mb, from CTB-56N23 to RP11-194A21 (Figure 3). The karyotype of the proband was thus interpreted as 46,XY,rec(4)dup(4p)inv(4)(p15.1q35.1).arr 4p16.3p15.1(CTD-218L8 $\rightarrow$ RP11-405D14)x3,4q35.1q35.2 (CTB-56N23 $\rightarrow$ RP11-194A21)x1 pat.

\section{Discussion}

Recombinant chromosome 4 is a rare chromosomal anomaly. Including our patient, only 11 cases have been described to date $[7,10-16,19]$. Surprisingly, all cases have the same or very close breakpoints and all inherited the recombinant chromosome 4 from a parent who carried a pericentric inversion of chromosome 4 .

A comparison of the breakpoints between patients with recombinant 4 syndrome (Table 1 ) indicated that all cases had either the same or very close breakpoints, within sub-bands $\mathrm{p} 13 \sim \mathrm{p} 15$ and $\mathrm{q} 35$. This consistency was most evident between our patient and another case in which array-CGH was used to more precisely characterize the breakpoints: both showed breakpoints at p15.1 and q35.1. There is increasing evidence for the involvement of repetitive DNA sequences as facilitators of some recurrent chromosomal rearrangements. We suggest that the similarity of breakpoints in all reported rec(4) patients might be due to the presence of these repetitive DNA sequences, which facilitate recurrent pericentric inversions at these chromosomal regions.

The clinical phenotype of $\mathrm{rec}(4)$ has been a subject of debate. In a review of clinical features in patients with rec(4) dup 4p, Garcia-Heras et al. argued that rec(4) dup $4 \mathrm{p}$ is not characterized by a clinically recognizable phenotype [7]. Possible reasons include variations in the sizes of the 4q deletion, differences in the breakpoints, and variable expression of the trisomic 4p [7]. In contrast, Bataglia et al. suggested that rec (4) dup 4p appears to be a discrete entity with relatively consistent 


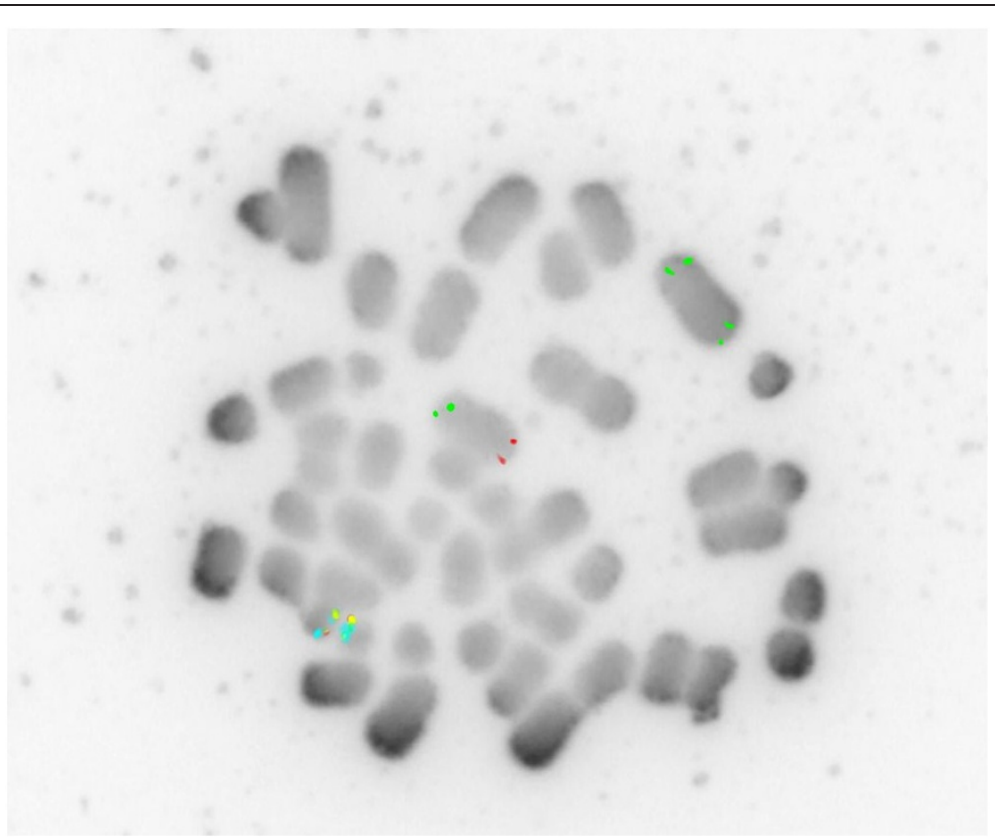

Figure 2 Inverted DAPI image of proband metaphase using Subtel $4 p$ probe (green) and Subtel $4 q$ (red).

features [15]. To clarify this argument, we compared the clinical features of all 11 patients with rec(4) reported to date (Table 1). Most of these features, such as growth retardation, microcephaly, abnormal ears, pointed chin, broad chest, short neck, thin upper lips, and broad nose with anteverted nares, were found in all cases. Genital anomalies were reported in all males, and cardiac defects were reported in 5 of 11 patients.

To further evaluate associations between specific chromosome 4 rearrangements and clinical features, we also conducted a genotype-phenotype correlation study of previously reported cases of $\operatorname{rec}(4), \operatorname{dup}(4 \mathrm{p})$, and del (4q) syndromes (Table 2) . Urogenital abnormalities and cardiac defects were common to rec(4) and $\operatorname{del}(4 \mathrm{q})$ syndrome, indicating their association with the $4 \mathrm{q} 35$ deleted region. The consistency of the other clinical features in both rec(4) syndrome cases and $\operatorname{dup}(4 \mathrm{p})$ cases indicates their association with the 4p15.1 duplicated region. In support of our findings, previous reports $[20,21]$ indicated that cardiac defects are rarely observed in dup $4 p$ patients whose duplication involves the same region affected in rec(4) patients. In addition, Maurin and

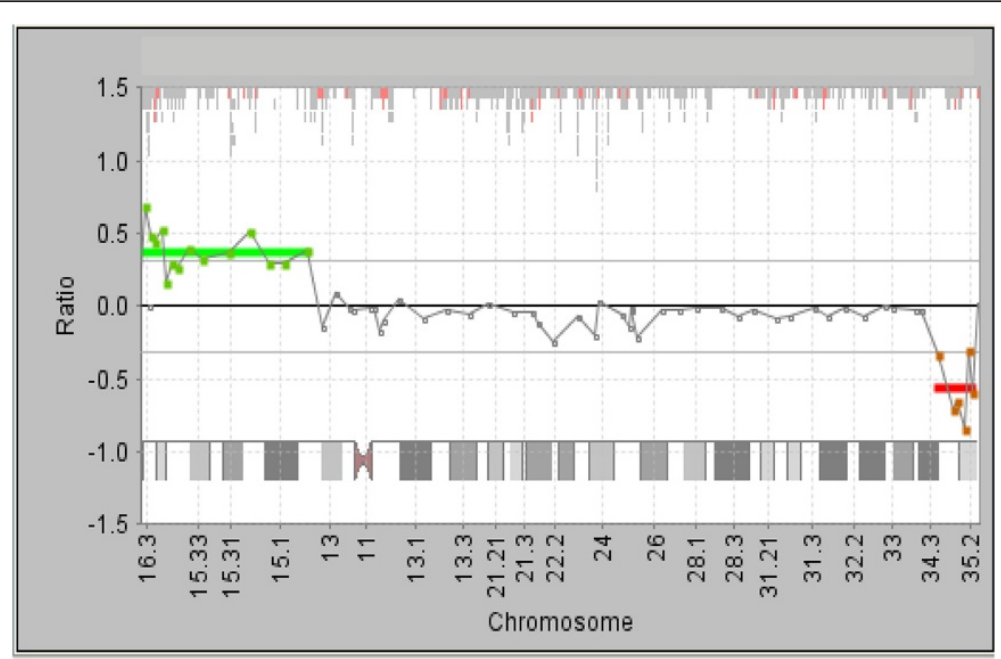

Figure 3 Expanded chromosome 4 aCGH showing 1) a duplicated segment of $4 \mathrm{p} 15.1 \rightarrow 4 p t e r$ with gain of at least $23.81 \mathrm{Mb}$; and 2) a deleted segment of $4 q 35.1 \rightarrow 4 q$ ter with loss of at least $4.36 \mathrm{Mb}$ of distal $4 \mathrm{q}$. 
Table 1 Comparison of the clinical features of the present case and ten other reported cases of recombinant chromosome 4

\begin{tabular}{|c|c|c|c|c|c|c|c|c|c|c|c|c|}
\hline Patients & Sex & $\begin{array}{l}\text { Parental } \\
\text { inversion }\end{array}$ & $\begin{array}{c}\text { Growth } \\
\text { retardation }\end{array}$ & $\begin{array}{l}\text { Micro- } \\
\text { cephaly }\end{array}$ & $\begin{array}{l}\text { Pointed } \\
\text { chin }\end{array}$ & $\begin{array}{c}\text { Broad } \\
\text { nose }\end{array}$ & $\begin{array}{c}\text { Thin } \\
\text { upper lips }\end{array}$ & $\begin{array}{l}\text { Abnormal } \\
\text { ears }\end{array}$ & $\begin{array}{c}\text { Short } \\
\text { neck }\end{array}$ & $\begin{array}{c}\text { Broad } \\
\text { chest }\end{array}$ & $\begin{array}{c}\text { Cardio- } \\
\text { pathy }\end{array}$ & $\begin{array}{c}\text { Genital } \\
\text { anomaly }\end{array}$ \\
\hline $\begin{array}{l}1974 \\
(10)\end{array}$ & $\mathrm{F}$ & p13q35 & + & + & + & + & + & + & + & + & + & - \\
\hline $\begin{array}{l}1974 \\
(11)\end{array}$ & M & $p 14 q 35$ & + & + & + & + & + & + & + & + & + & + \\
\hline $\begin{array}{l}1992 \\
(12)\end{array}$ & F & p14q35.2 & $\mathrm{nr}$ & + & + & + & + & + & + & + & $\mathrm{nr}$ & $\mathrm{nr}$ \\
\hline $\begin{array}{l}1993 \\
(13)\end{array}$ & F & p15.32q35 & $\mathrm{nr}$ & $\mathrm{nr}$ & $\mathrm{nr}$ & $\mathrm{nr}$ & $\mathrm{nr}$ & + & $\mathrm{nr}$ & $\mathrm{nr}$ & $\mathrm{nr}$ & $\mathrm{nr}$ \\
\hline $\begin{array}{l}2000 \\
(14)\end{array}$ & F & p16q35.1 & + & + & + & + & + & + & + & $\mathrm{nr}$ & $\mathrm{nr}$ & - \\
\hline $\begin{array}{l}2002 \\
(15)\end{array}$ & M & $p 14 q 35$ & + & + & + & + & + & + & + & + & + & + \\
\hline $\begin{array}{l}2002 \\
\text { (7) }\end{array}$ & F & p15q35 & + & + & + & + & + & + & + & + & + & - \\
\hline $\begin{array}{l}2007 \\
(16)\end{array}$ & F & p14q35 & + & + & + & + & + & + & + & + & - & - \\
\hline $\begin{array}{l}2007 \\
(16)\end{array}$ & F & p14q35 & - & + & + & + & + & + & + & + & - & - \\
\hline $\begin{array}{l}2009 \\
(21)\end{array}$ & M & p15.1q35 & + & - & + & + & + & + & + & + & + & + \\
\hline $\begin{array}{l}\text { our } \\
\text { case }\end{array}$ & M & p15.1q35 & + & + & + & + & + & + & + & + & + & + \\
\hline
\end{tabular}

F, female; M, male; +, present; -, absent; $\mathrm{nr}$, not reported.

colleagues [19] found the ArgBP2 and PDLIM3 genes in the $4 \mathrm{q} 35.1$ deleted region to be involved in cardiac muscle development. Similarly, urogenital abnormalities, which have rarely been reported in $\operatorname{dup}(4 \mathrm{p})$ cases, have been consistently reported in 4q deletion syndrome and male rec(4) patients $[11,15,19,22]$. Therefore, we propose that the genes involved in male genital anomalies are located on $4 \mathrm{q}$.

\section{Conclusion}

In conclusion, our findings support that the clinical features of patients with rec(4) are relatively consistent and specific to the regions of duplication or deletion. Recombinant chromosome 4 syndrome thus appears to be a discrete entity that can be suspected on the basis of clinical features or specific deleted and duplicated chromosomal regions.

Table 2 Comparison of the common clinical features of the $\operatorname{rec}(4)[7,10-16,19]$, dup $(4 p)[20,21]$ and del(4q) $[22]$ syndromes

\begin{tabular}{lccc}
\hline & rec(4) syndrome & dup(4p) syndrome & del(4q) syndrome \\
\hline Growth retardation & + & + & - \\
Microcephaly & + & + & - \\
Abnormal ears & + & + & - \\
Pointed Chin & + & + & - \\
Broad chest & + & + & - \\
Short neck & + & + & - \\
Thin upper lip & + & + & - \\
Broad nose & + & + & - \\
Cardiopathy & + & - & - \\
Urogenital abnormality & + & - & + \\
\hline
\end{tabular}

+, present; -, absent; nr, not reported. 


\section{Methods}

Peripheral blood samples from a one year-old boy was referred to our laboratory for cytogenetic analysis. Metaphase chromosome preparations were obtained from the patient according to standard procedures. Chromosomes were analyzed with G-banding at the resolution level of 550 bands. To confirm the duplicated and deleted regions, fluorescent in situ hybridization (FISH) analysis was performed with the Tel4pter and Tel4qter probes (Telvysion; Vysis/Abbott, Inc., Downers Grove, IL).

To define the break points and extent of the duplicated and deleted segments, we performed array-CGH using a $1-\mathrm{Mb}$ BAC array with 3222 clones, spaced no more than $1 \mathrm{Mb}$ apart (Quest Diagnostics), scanned on GenePix 4000B microarray scanner (Axon Instruments), and analyzed with Clarisure software. Labeling and hybridization were performed using standard procedures.

\section{Ethical approval and consent}

These studies were performed on anonymized samples received in the clinical laboratory and thus were exempted from the requirement for consent by an opinion for the Western Institutional review Board.

\section{Abbreviation}

rec(4): Recombinant chromosome 4; dup(4p): Duplicated short arm of chromosome 4; del(4q): Deleted long arm of chromosome 4;

$\mathrm{CGH}$ : Comparative genomic hybridization; Mb: Mega base.

\section{Competing interest}

The authors declare that they have no competing interest.

\section{Authors' contribution}

$\mathrm{MH}$ and $\mathrm{OH}$ First co-authors; performed analysis, interpretation of the results, drafting and finalizing the manuscript. TS and MEN participated in writing the case description and revision of the manuscript. BTW, JCW, AA, FZB and $\mathrm{RO}$ participated in the revision of the manuscript. All authors read and approved the final manuscript.

\section{Acknowledgement}

The authors would like to express their thanks to Jeff S. Raddiff (Quest Diagnostics) for assistance in editorial review of the manuscript.

\section{Author details}

${ }^{1}$ Cytogenetics Department, Quest Diagnostics Nichols Institute, San Juan Capistrano, CA, USA. ${ }^{2}$ Ostrow School of Dentistry, University of Southern California, Los Angeles, CA, USA. ${ }^{3}$ Cytogenetics Department, Quest Diagnostics Nichols Institute, 33608 Ortega Highway, San Juan Capistrano, CA 92690, USA.

\section{Received: 29 December 2012 Accepted: 1 March 2013}

Published: 2 May 2013

\section{References}

1. Oshima J, Lee JA, Breman AM, Fernandes PH, Babovic-Vuksanovic D, Ward PA, Wolfe LA, Eng CM, Del Gaudio D: LCR-initiated rearrangements at the IDS locus, completed with Alu-mediated recombination or nonhomologous end joining. J Hum Genet 2011, 56:516-523.

2. Gabriel-Robez O, Ratomponirina C, Rumpler Y, Le Marec B, Luciani JM, Guichaoua MR: Synapsis and synaptic adjustment in an infertile human male heterozygous for a pericentric inversion in chromosome 1. Hum Genet 1986, 72:148-152
3. Trunca C, Opitz JM: Pericentric inversion of chromosome 14 and the risk of partial duplication of 14q (14q31 leads to 14qter). Am J Med Genet 1977, 1:217-228

4. Daniel A: Structural differences in pericentric inversions. Application to model of risk of recombinants. Hum Genet 1981, 56:321-328.

5. Kaiser $P$, Forster W, Steuernagel $P$, Hillig U, Herberg KP: Familial pericentric inversion (14) $(p 11 ; q 24)$ with a rec $\operatorname{dup}(q)$ in one offspring. Clin Genet 1984, 26:73-76.

6. Winsor EJ, Palmer CG, Ellis PM, Hunter JL, Ferguson-Smith MA: Meiotic analysis of a pericentric inversion, inv(7) (p22q32), in the father of a child with a duplication-deletion of chromosome 7. Cytogenet Cell Genet 1978, 20:169-184.

7. Garcia-Heras J, Martin J: A rec(4) dup $4 p$ inherited from a maternal inv(4) (p15q35): case report and review. Am J Med Genet 2002, 109:226-230.

8. Gardner RJ, Sutherland GR, Shaffer LG: Chromosome abnormalities and genetic counseling. New York: Oxford University Press; 2012.

9. Wilson MG, Towner JW, Coffin GS, Forsman I: Inherited pericentric inversion of chromosome no. 4. Am J Hum Genet 1970, 22:679-690.

10. Dallapiccola B, Capra L, Preto G, Covic M, Dutrillaux B: Pericentric inversion of chromosome 4: inv (4) (p13, q35) and trisomy of the short branch of chromosome 4 due to recombination aneusomy. Ann Genet 1974, 17:115-118.

11. Rethore MO, Dutrillaux B, Job JC, Lejeune J: Trisomy $4 p$ due to recombination aneusomy of an inversion 4 (p14, q35). Ann Genet 1974, 17:109-114.

12. Kleczkowska A, Fryns JP, van den Berghe H: Trisomy of the short arm of chromosome 4: the changing phenotype with age. Ann Genet 1992, 35:217-223.

13. Hirsch $B, B a l d i n g e r ~ S:$ Pericentric inversion of chromosome 4 giving rise to $\operatorname{dup}(4 p)$ and dup $(4 q)$ recombinants within a single kindred. Am J Med Genet 1993, 45:5-8.

14. Dufke A, Eggermann K, Balg S, Stengel-Rutkowski S, Enders H, Kaiser P: A second case of inv(4)pat with both recombinants in the offspring: rec dup(4q) in a girl with Wolf-Hirschhorn syndrome and rec dup(4p). Cytogenet Cell Genet 2000, 91:85-89.

15. Battaglia A, Brothman AR, Carey JC: Recombinant 4 syndrome due to an unbalanced pericentric inversion of chromosome 4. Am J Med Genet 2002, 112:103-106.

16. Stembalska A, Laczmanska I, Schlade-Bartusiak K, Czemarmazowicz H, Murawski M, Sasiadek M: Recombinant chromosome 4 resulting from a maternal pericentric inversion in two sisters presenting consistent dysmorphic features. Eur J Pediatr 2007, 166:67-71.

17. Mun SJ, Cho EH, Chey MJ, Shim GH, Shin BM, Lee RK, Ko JK, Yoo SJ: Recombinant chromosome 4 with partial $4 p$ deletion and $4 q$ duplication inherited from paternal pericentric inversion. Korean J Lab Med 2010, 30:89-92.

18. Lee J, Han K, Meyer TJ, Kim HS, Batzer MA: Chromosomal inversions between human and chimpanzee lineages caused by retrotransposons. PLoS One 2008, 3:e4047.

19. Maurin ML, Labrune P, Brisset S, Le Lorc'h M, Pineau D, Castel C, Romana S, Tachdjian G: Molecular cytogenetic characterization of a 4p15.1-pter duplication and a 4q35.1-qter deletion in a recombinant of chromosome 4 pericentric inversion. Am J Med Genet A 2009, 149A:226-231.

20. Patel SV, Dagnew H, Parekh AJ, Koenig E, Conte RA, Macera MJ, Verma RS: Clinical manifestations of trisomy $4 p$ syndrome. Eur J Pediatr 1995, 154:425-431.

21. Schinzel A: Catalogue of unbalanced chromosome aberrations in man. New York: Walter de Gruyter; 2001

22. Kuldeep CM, Khare AK, Garg A, Mittal A, Gupta L: Terminal 4q deletion syndrome. Indian J Dermatol 2012, 57(3):222-224.

doi:10.1186/1755-8166-6-17

Cite this article as: Hemmat et al:: Genotype-phenotype analysis of recombinant chromosome 4 syndrome: an array-CGH study and literature review. Molecular Cytogenetics 2013 6:17. 